\title{
Endoscopic and Echo-sonographic Monitoring in Aneurysm Surgery
}

\author{
Yoshie Hara, M.D., Norihiko TAmaki, M.D., \\ Yoshimasa TAKaishi, M.D., Mitsugu NaKamura, M.D.
}

\begin{abstract}
Summary: We outline our initial experience with intraoperative endoscopic and sonographic monitoring for aneurysm surgery. During the last two years, endoscopic and sonographic monitoring was performed for six patients who underwent direct aneurysm clipping. We used a straight or angled rigid neuroendoscope fixed to the operative table, and observed the aneurysm and surrounding neurovascular structures during dissection and clip application. After the clip was placed, observation was done by free-hand manipulation of the endoscope. A microvascular Doppler sonography was used to document blood flow pattern in the artery near the aneurysm and in the aneurysmal neck and dome.

By endoscopic monitoring we could observe the dead-angles of the microscopic view with strong magnification and bright illumination and reduce retraction and dissection around the aneurysmal neck. We preferred the angled endoscope during clip application because it did not collide with the microscope or surgical instruments while maintaining satisfactory image quality. After the clip was properly placed, a normal blood flow pattern was noted in the parent artery and other branches, while no flow was detected inside the aneurysm. No complication due to this monitoring occurred. A combination of these two modalities could contribute to less invasive and more accurate aneurysm surgery.
\end{abstract}

\author{
Key words: \\ - angled endoscope \\ - microvascular Doppler \\ - aneurysm \\ - microsurgery
}

Surg Cereb Stroke

(Jpn) 27: 121-124, 1999

\section{Introduction}

As the trend in recent neurosurgery moves toward less invasiveness, intraoperative monitorings are becoming more and more important. These include visual monitoring using sonography, endoscope, ${ }^{4) 699) 10}$ and intraoperative computed tomographic scan, and functional monitoring as electrophysiological monitors and Doppler flow monitoring. ${ }^{5)}$ This report is focused on our experience with combined endoscopic and sonographic monitoring during direct aneurysm surgery.

\section{Patients and Methods}

Between October 1997 and April 1998, both endoscopic and sonographic monitoring was performed for six cases who underwent direct aneurysm clipping under general anesthesia. These included three internal carotid-posterior communicating artery aneurysms, two middle cerebral artery aneurysms, and one basilar tip aneurysm. One was a ruptured aneurysm and others were unruptured.

We utilized straight rigid neuroendoscopes $(4.0 \mathrm{~mm}$ in diameter, 110 degree visual angle, 0, 30, and 70 degree visual direction, Machida Co., Ltd., Tokyo, Japan), and angled rigid endoscope which was designed by N. Tamaki and constructed by Machida Co., Ltd. (Tokyo, Japan). This angled scope has a 110 degree angulation at the middle portion of its shaft which is $2.7 \mathrm{~mm}$ in diameter. The visual angle is 75 degree, and visual direction is 0,30 , and 70 degree. After the dura was incised and the parent artery observed, the endoscope was held by the surgeon and 
brought into the operative field. After free-hand observation, the scope was positioned so that it could observe from the opposite side of the microscopic inspection. Then the endoscope was attached to the operative table with aid of flexible arm (Machida Co., Ltd., Tokyo, Japan) to allow the surgeon to use both hands for microsurgical procedure under continuous endoscopic monitoring. While dissection and clip application, microscopic and endoscopic images were displayed in picture-in-picture fashion on a small liquid-crystal monitor facing the surgeon. The surgeon looked at both the microscopic and endoscopic images during the procedure. After the clip was applied, the surgeon manipulated the endoscope for further free-hand inspection. For blood flow monitoring, a $20 \mathrm{MHz}, 1 \mathrm{~mm}$ diameter microvascular Doppler sonography was used to assess the patency of the parent artery, branches, and the flow in the aneurysmal neck and dome before and after clip application.

\section{Results}

In all cases the aneurysm was completely occluded. We experienced no complication related to the manipulation of the endoscope or the micro-Doppler probe. There was no postoperative clinical deterioration nor abnormal density on postoperative computed tomographic scans.

1) Endoscopic monitoring

Continuous endoscopic monitoring was successfully performed in all cases. By endoscopic observation from the opposite side of the microscopic manipulation, we could look into the dead angles of the microscopic view during dissection and clip application. In surgery for internal carotid artery aneurysms, the endoscope could clearly delineate the origin of the posterior communicating artery and perforating arteries arising from it. The relationship between the clip blades and the aneurysmal neck or perforating arteries were very precisely delineated (Fig. 1AD). In surgery for basilar tip aneurysm, the endoscope could show the contralateral posterior cerebral and superior cerebellar arteries very clearly. When the head of the clip obscured further microscopic view, the endoscope was especially helpful.

2) Sonographic monitoring

The Doppler microprobe was able to insonate all vessels of the circle of Willis, their major branches, and perforating arteries were reliably insonated. We could obtain normal arterial flow velocity waveform before clip application from these arteries. The blood flow in the aneurysm was turbulent. After the clip was applied, all but one major artery showed unchanged, normal flow, and the blood flow in the aneurysm disappeared (Fig. 1D-E). In one case with a middle cerebral artery aneurysm, Doppler showed a decreased wave amplitude at the M2 portion of the middle cerebral artery, which suggested partial obstruction by the clip. Immediate re-adjustment of the aneurysm clip resulted in normal arterial waveform on micro-Doppler.

\section{Discussions}

For sufficient clip application, the surgeon has to dissect and to look around the aneurysmal neck very carefully. Retraction of the aneurysm, parent artery, branches and surrounding neural structures is sometimes required for further observation, which may lead to intraoperative aneurysmal rupture, distal embolism, or cranial nerve or brain damage. With the aid of endoscope, we can get more illumination and obtain strongly magnified views of otherwise hidden structures while reducing brain retraction. ${ }^{2) 11)}$ Some surgical procedures which we previously performed blindly can be undertaken more safely and accurately under clear, bright endoscopic view. ${ }^{6) 7)}$ By combining micro Doppler evaluation, ${ }^{1) 3) 8)}$ the surgeon is convinced of total neck occlusion not only visually but on the the absence of blood flow inside the aneurysm.

Although rigid neuroendoscopes have shorter shafts compared to endoscopes for other uses, the shafts of commercially available rigid neuroendoscopes often interfere with microsurgical procedures, sometimes by collision with the microscope or other operative instruments in the narrow space under the microscope. Therefore continuous intraoperative monitoring with a rigid neuroendoscope has been hazardous. Our angled rigid endoscope is designed specifically for continuous intraoperative monitoring. Its slender shaft has a $110^{\circ}$ angulation which ensures that the bulky camera and accessories are outside the operative field. Thus the surgeon can perform procedures under microscopic and endoscopic monitoring without loss of space in which to maneuver. We have one problem related to our combined monitoring method. It is that the surgeon has to look at the operative microscope and endoscopic monitor at the same time and has to shift his eyes. This may lead to mismanipulation which can be critical during clip application. We are working on a new type that displays the microscopic and endoscopic images inside the microscopic view. ${ }^{6) 11}$

In this series most of the patients had unruptured cerebral aneurysms. Surgery for unruptured, asymptomatic aneurysm requires the most accuracy and allows the least invasion. Therefore we emphasize on that combined endoscopic and sonographic monitoring can be especially helpful. 


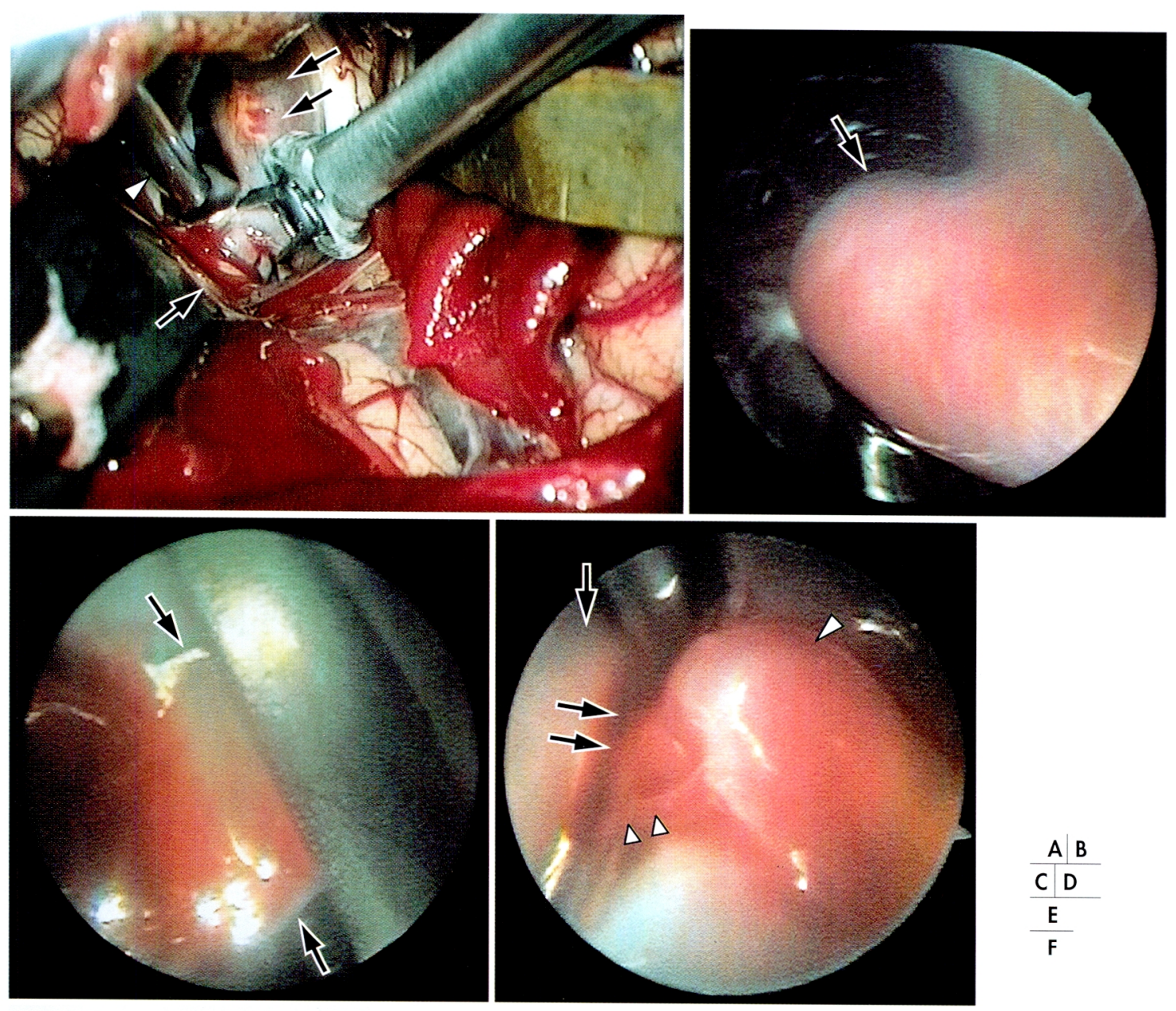

Fig. 1 Case 1: Left internal carotid-posterior communicating artery aneurysm operated on via left fronto-temporal craniotomy.

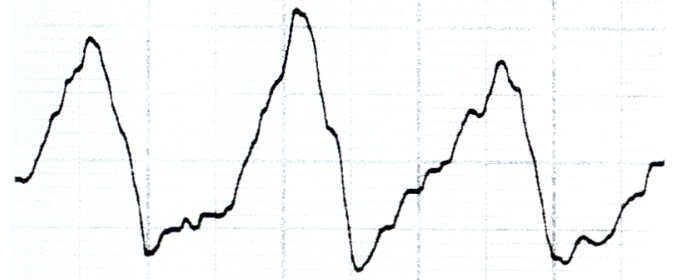

A. Intraoperative microscopic view while clip application. Because there was adhesion between the aneurysmal dome and the left temporal lobe (arrow), retraction of ICA (double arrow) was not possible, nor further microscopic observation. The endoscope was placed in the lateral side of the internal carotid artery (arrowhead). B. Intraoperative endoscopic view showed the origin of the posterior communicating artery (arrow), which looked like an aneurysm. C. The blade of the clip was observed during application. It was confirmed that the clip occluded the aneurysmal neck (arrow) completely while not affecting the origin of the posterior communicating artery.

D. The aneurysm (arrow), clip (double arrow), the posterior communicating artery (arrowhead), and a perforating artery arising from it (double arrowhead) are demonstrated. Note that the perforating artery is running between the blade of the clip and the internal carotid artery.

E. Doppler waveform was obtained from the posterior communicating artery after clip application. Normal arterial flow velocity wavetorm was noted.

F. Doppler waveform was obtained from the aneurysmal dome after clip application. No flow was noted. 


\section{Conclusions}

Intraoperative endoscopic monitoring was an effective method to observe the dead angle of the microscopic view and to reduce retraction of neurovascular structures. Angled endoscope was especially effective for continuous intraoperative monitoring. Microvascular Doppler sonography was a safe, instantaneous, and reliable method for documenting the patency of parent vessels, arterial branches, and major perforators and the complete occlusion of cerebral aneurysm. Combined endoscopic and sonographic monitoring made direct clipping of cerebral aneurysms safer and more accurate.

\section{References}

1) Bailes JE, Tantuwaya LS, Fukushima T, et al: Intraoperative microvascular Doppler sonography in aneurysm surgery. Neurosurgery 40: 965-970, 1997

2) Caemaert J, Abdullah J, Calliauw L: A multipurpose cerebral endoscope and neurosurgery. Acta-Neurochir-Suppl-Wien 61: 49-53, 1994

3) Edelmann M, Dehof S, Hegelmaier C, et al: Intraoperative micro-Doppler studies for clarifying the fluid dynamics in carotid thromboendoarterectomy-experiences and results of 237 operations. Vasa Suppl 35: 85-86,1992

4) Fischer J, Mustafa H: Endoscopic-guided clipping of cerebral aneurysms. Br-J Neurosurgery 8: 559-565, 1994

5) Laborde G, Gilsbach J, Harders A: The microvascular Doppler-an intraoperative tool for the treatment of large and giant aneurysms. Acta Neurochir Suppl Wien 42: 75-80, 1988

6) Levy ML, Day JD, Albuquerque F, et al: Heads-up intraoperative endoscopic imaging: a prospective evaluation of techniques and limitations. Neurosurgery 40: 526-530, 1997

7) Matula C, Tschabitscher M, Day JD, et al: Endoscopically assisted microneurosurgery. Acta Neurochir Wien 134: 190-195, 1995

8) Padayachee TS, Gosling RG, Bishop CC, et al: Monitoring middle cerebral artery blood velocity during carotid endoarterectomy. Br J Surg 73: 98-100, 1986

9) Perneczky A, Fries G: Endoscope-assisted brain surgery: Part 1-Evolution, basic concept, and current technique. Neurosurgery 42: 219-225, 1998

10) Perneczky A, Fries G: Endoscope-assisted brain surgery: Part 1-Analysis of 380 procedures. Neurosurgery 42: 226-231, 1998

11) Taneda M,Kato A, Yoshimine T, et al: Endoscopic-image display system mounted on the surgical microscope. Minim Invasive Neurosurg 38: 85-86, 1995
脳動脈瘤手術において顕微鏡手術の支援システムとして内視鏡 および超音波装置を用いた。脳動脈瘤に対して開頭手術を行った 6 例 (脳底動脈先端部 1 例, 内頸動脈後交通動脈分岐部 3 例, 中大 脳動脈 2 例) を対象とした．親動脈抢よび分枝や穿通枝と動脈瘤 頸部を露出後，ストレート型あるいは当施設の玉木が開発したア ングル型硬性内視鏡の先端を動脈溜頸部や親動脈の背側を観察で きるように挿入し，アーム型固定器で固定した. 手術中は顕微鏡 と内視鏡の両面面をモニター上に表示し, 観察しながらクリッピ ングを行った.クリッピング後は親動脈と分枝の血流をマイクロ ドップラーにて観察した.
アングル型内視鏡は手術操作の支障となることなく術中モニ夕 一が可能で，顕微鏡の死角となる親動脈㧍よび分枝や穿通枝など を観察しながらクリッピングを行うことができた。 そのため, 動 脈瘤周辺での剝離操作を減少できた. クリッピング後にマイクロ ドップラーにて親動脈や分枝の血流が保たれていることを確認し た.1例では血流障害を認めたためクリップをかけな抢した。全 例でネッククリッピングを行い，合併症は認めなかった。

動脈瘤に対する直達手術の安全性を向上させるために，内視鏡 や超音波を使用したモニタリングは有効であった。 